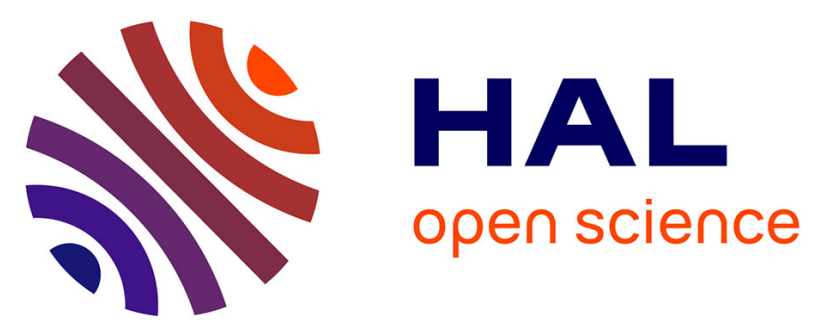

\title{
Poverty and Livelihood Diversification in Rural Liberia: Exploring the Linkages Between Artisanal Diamond Mining and Smallholder Rice Production
}

Gavin Hilson, Steven van Bockstael

\section{- To cite this version:}

Gavin Hilson, Steven van Bockstael. Poverty and Livelihood Diversification in Rural Liberia: Exploring the Linkages Between Artisanal Diamond Mining and Smallholder Rice Production. The Journal of Development Studies, 2012, 48 (03), pp.413-428. 10.1080/00220388.2011.604414 . hal-00807098

\section{HAL Id: hal-00807098 \\ https://hal.science/hal-00807098}

Submitted on 3 Apr 2013

HAL is a multi-disciplinary open access archive for the deposit and dissemination of scientific research documents, whether they are published or not. The documents may come from teaching and research institutions in France or abroad, or from public or private research centers.
L'archive ouverte pluridisciplinaire HAL, est destinée au dépôt et à la diffusion de documents scientifiques de niveau recherche, publiés ou non, émanant des établissements d'enseignement et de recherche français ou étrangers, des laboratoires publics ou privés. 


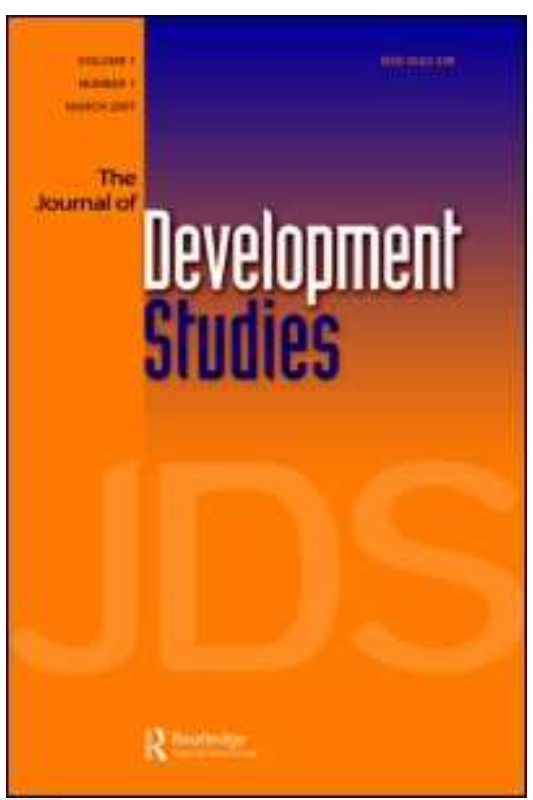

Poverty and Livelihood Diversification in Rural Liberia: Exploring the Linkages Between Artisanal Diamond Mining and Smallholder Rice Production

\begin{tabular}{|r|l|}
\hline Journal: & Journal of Development Studies \\
\hline Manuscript ID: & FJDS-2010-Oct-0024.R1 \\
\hline Manuscript Type: & Original Manuscripts \\
\hline Keywords: & $\begin{array}{l}\text { Diversification < Economics, Agricultural development < Economics, } \\
\text { Mining/extractive industries < Economics, Africa < Geographical } \\
\text { Area, Rural < Human Geography }\end{array}$ \\
\hline \multicolumn{2}{|c}{} \\
\hline
\end{tabular}

\section{SCHOLARONE $^{\text {IM }}$ \\ Manuscripts}




\begin{abstract}
This paper provides an account of the changing livelihood dynamics unfolding in diamondrich territories of rural Liberia. In these areas, many farm families are using the rice harvested on their plots to attract and feed labourers recruited specifically to mine for diamonds. The monies accrued from the sales of all recovered stones are divided evenly between the family and hired hands, an arrangement which, for thousands of people, has proved to be an effective short-term buffer against poverty. A deepened knowledge of these dynamics could be an important step towards facilitating lasting development in Liberia's highly-impoverished rural areas.
\end{abstract}




\section{Introduction}

On 22 April 2008, The BBC published an article, 'Liberians Drop Rice for Spaghetti' on its website. ${ }^{1}$ The headline captures the magnitude of the development challenge facing Liberia, a country struggling mightily to recover from a lengthy and debilitating civil war. Scores of people who had fled during two recent and lengthy episodes of violence (1989-1996, 1999-2003) have since attempted to re-enter their lives. They have returned to a country, however, with few economic prospects; a decimated agricultural foundation; and a market flooded with imported American-produced foodstuffs, particularly rice, long the staple food of the population. According to the latest UNDP Human Development Index, Liberia ranks 169 out of 182 countries. Close to 85 percent of the national population subsists on a daily wage of less than US\$1.25, and annual GDP per capita is in the range of US\$130 (UN, 2009).

For Liberia, the priority is becoming self-sufficient, particularly in the area of rice production something which, despite the rhetoric, a reconstruction effort now in its eighth year has not come close to achieving. Liberians are struggling to survive, to the point where a growing number are dropping from their diets imported rice, the price of which has increased by 60 percent since December 2007 (USAID, 2010), in favour of less costly imported foodstuffs such as spaghetti. Although the government is working 'to create an open economy with low tariff and non-tariff barriers, [with] strong linkages to international markets' (IMF, 2008 , p. 22), this is by no means achievable in the short term. It is clearly a long-term vision: with only nine percent of the country's rural population being food secure, there are more immediate concerns. One of the most significant challenges is feeding, more effectively, a rural population that is 90 percent food insecure. Even the government is beginning to recognize the precariousness of the situation, and is encouraging rural households to grow their own food. To this end, the Ministry of Agriculture has erected countless signboards across the country on which the phrase 'Grow What You Eat, Eat What You Grow' has been inscribed in bolded letters (Figure 1). This message is fast becoming the motto for survival in the country's rural areas.

To free themselves from the burden of food costs, principally purchases of imported - primarily American - rice, many returning rural Liberians have intensified production of local rice. This has helped to reduce household expenditure on food considerably. But perhaps more importantly, it has allowed many household heads to turn their attention to artisanal diamond mining, an economic activity with far greater potential to generate disposable income and, in the process, raise rural families' living standards. Scattered across the very plots of land on which many individuals are harvesting their rice crops are countless alluvial 


\section{Smallholder Rice Production and Artisanal Diamond Mining: An Emerging Pattern of Livelihood Diversification in Rural Liberia?}

Across sub-Saharan Africa, rural livelihood diversification is widespread (Barrett et al., 2001). Over the past two decades, a burgeoning literature has emerged (e.g. Bryceson 1996, Ellis 1998) which details the phenomenon. It also offers an assortment of explanations for why rural farm families 'branch out' into the nonfarm economy. Whilst the specific motivations for doing so vary, this movement is generally linked to the inability of agriculture to fully provide the financial requirements of households on its own. The situation in Liberia is somewhat unique in this context because unlike most countries in sub-Saharan Africa, it is nowhere close to having a productive agricultural base. The ubiquitous sights that are frequently associated with rural sub-Saharan Africa - banana vendors, stockpiles of citrus, yams and cassava sold along the roadside in makeshift shelters, and scores of goats and sheep - are visibly absent in Liberia, yet to be restored following two lengthy episodes of civil violence. The contentious issue across most of sub-Saharan Africa is whether the smallholder model promoted under an extended period of structural adjustment and which continues to be a 
centrepiece of most Poverty Reduction Strategy Papers (PRSPs) ${ }^{2}$ is, indeed, viable: intensified and relatively unsupported production of devalued cash crops for export such as tea, coffee, pineapple and bananas (after Ellis, 2006). But for war-torn Liberia, which is in no position to entertain implementing such a strategy, the priority is restoring its agricultural productive base.

Recognizing the importance of doing so, the government has stated in its Comprehensive Assessment of the Agricultural Sector (MoA, 2007) that 'agriculture continues to be at the centre of reconstruction and development efforts' (p. 1). Judging from the text contained within the country's PRSP, the vision is twopronged: first, to make Liberia food secure; and second, once this is achieved, to connect smallholders to international markets. This undertaking, however, is by no means straightforward for a number of reasons. First, and foremost, despite claiming that smallholder agricultural development is a central pillar of the reconstruction effort, the government's actions suggest otherwise: only a paltry US\$11.7 million of the US\$526 million national budget for 2010/11 has been earmarked for 'Food and Agriculture'. Even the country's president, Ellen Johnson Sirleaf, has acknowledged that current level of public funding for agricultural development 'is woefully inadequate', pointing out in a recent speech that 'the share of our [Liberia's] national budget allocated to agricultural institutions and activities rose from US\$3 million in 2006 to US\$7 million in 2009 but this still represents a mere 2 percent of our [Liberia's] budget' (Sirleaf, 2010, p. 2). Even if these modest sums did manage to mobilize fairly robust support programs, deteriorated infrastructure would likely undermine earning opportunities. The country's road network is in shambles, which makes access to remote areas challenging during the rainy season. At present, there are only $700 \mathrm{~km}$ of surfaced roads - most of which are damaged - and $5600 \mathrm{~km}$ of unpaved roads across Liberia (Government of Liberia, 2008). Moreover, several bridges were damaged in the war; the national railway network has not been operational for over 20 years; and at the time of the 2005 national election, there had been no piped water or electricity (outside of small private generators) in Liberia for 15 years (IMF, 2008). For smallholder activity to flourish, infrastructure must be restored.

Second, there is the herculean task of figuring out how to reduce dependence on imported American rice. In 2007/08, domestic rice production satisfied only 40 percent of national demand. The balance was covered by imported produce purchased at high prices (UN, 2010a): of the 788,875.34 tonnes consumed over this period, approximately 542,506 tonnes was of non-Liberian origin (Fanou and Koiwou, 2009). As a share of total consumption, imported rice accounts for 30 percent of national food consumption costs (Tsimpo and Wodon, 2008). Looking to encourage rural Liberians to 'Grow What You Eat, Eat What You Grow' - an 
approach believed will help to rectify this problem - the government launched its 'Back to the Soil' campaign on 27 June 2009. A nationwide awareness and sensitization campaign implemented in 15 of the country's counties involving farmers, students, youth campaigners, musical artists, government officials, members of the private sector and civil society organizations, 'Back to the Soil' aims to reintegrate Liberians into smallholder farming. ${ }^{3}$ Programs such as 'Back to the Soil' have effected some change, notably in the area of domestic rice production, which rose from 85,000 metric tonnes in 2006 to 200,000 metric tonnes in 2009 (Sirleaf, 2010). But for the program to have a lasting impact, substantially more funding is needed than the modest US $\$ 100,000$ invested by the Department of Regional Development and Extension in farm implements and the additional US $\$ 260,000$ of agricultural supplies.

This links to a third reason, which is the current focus of Liberia's aid and the potential challenges with reorienting it. Although Liberia has been stable for several years, support for peace and security continue to be areas where most of its aid dollars flow. The approved budget of the UN Mission in Liberia (UNMIL), which was established by Security Council Resolution 1509 (2003), is an incredible US\$524,052,800 for the period July 2010-June 2011 (UN, 2009). The budgetary focus of USAID, which is by far Liberia's biggest bilateral donor, is cause for further concern. Of the US\$227 million allocated to the USAID Liberia Assistance Program in 2010, only US\$34 million and US\$18.5 million were spent on agriculture and infrastructural development, respectively (USAID, 2010). There could, of course, be political undertones at work here, given that the United States currently supplies a large share of Liberia's rice. Moreover, the country's trade in imported rice is dominated by a small group of powerful players who are in no way interested in relinquishing their stranglehold over supply to domestic producers because it would cut into profit margins: at present, there are only five licensed rice importers, who sell product in US dollars to intermediaries at Gobachop/Red Light Market in Paynesville. $^{4}$ These wholesalers proceed to sell rice to retailers - also in US dollars - who in turn sell to consumers in Liberian dollars (Government of Liberia, 2008; USAID, 2009). The dilemma potentially facing the government is how to proceed with dismantling a structure that must be altered markedly in order for domestic rice production to flourish but which - however inequitable it may be - has helped to bridge the gap between supply and demand for rice in a country where production dropped 75 percent between 1987 and 2005 . Not surprisingly, progress on this front has been exceedingly slow.

In fact, the entire reconstruction process in Liberia has been pedestrian. Despite the government's claim that it 'is working hard to revitalize agriculture as the bedrock of the economy... [and] is central to reducing poverty, providing food security, and ensuring progress toward the Millennium Development Goals' 
(IMF, 2008, p. 22), because of the aforementioned hurdles, restoration of Liberia's war-torn economy has been painfully slow process, with few signs of progress on the horizon. There is consensus that the targets set under the Millennium Development Goals (MDGs) 'are unlikely to be met', and that the 'lingering effects of the prolonged civil crisis have diminished hopes for positive outcomes in 2015' (USAID, 2010, p. 5). With few improvements expected to be made in the short term, 'Grow What You Eat, Eat What You Grow' seems like a logical remedy: even with the modest levels of technical support being pledged under programs such as 'Back to the Soil', scores of rural Liberians are managing to secure the tools and inputs to needed to generate sufficient supplies of rice to feed their families. Favourable climatic conditions, vast sections of arable land (4.6 million ha of the country's 9.8 million ha of land or 46 percent of its area), and significant irrigation potential (it has 600,000 ha of freshwater swampland) have enabled many rural families to begin growing rice and other staples, in subsistence quantities, with relative ease (FAO, 2008).

In localities such as Tubmanburg, the capital of Bomi County, by buying into a strategy of 'Grow What You Eat, Eat What You Grow', numerous rural families have improved their food security situations and reduced expenditure on food - principally, imported rice. At the time of the presidential election in 2005, only 20 percent of Bomi County's households were producing their own rice. Data are scarce but several NGOs, including NRC and the Red Cross, have distributed seeds to the county's families since the election, and the Chinese and Liberian governments have reportedly distributed tools and seed rice amounting to $18,122 \mathrm{~kg}$ to 50 communities (Government of Liberia, 2009). These efforts, in combination with the influence of the 'Back to the Soil' campaign, have helped to make hundreds of Bomi County's farm families more self-sufficient. It has also enabled the heads of these families to turn their attention to artisanal diamond mining, an economic activity capable of generating the disposable income desperately needed to improve quality-of-life.

But whilst a formalized and supported artisanal diamond mining could help to alleviate significant poverty in rural Liberia, the government remains ambivalent on what role it should play in the reconstruction process. The civil violence that has unfolded in not only Liberia and neighbouring Sierra Leone but also Angola and The Democratic Republic of Congo has cast a dark shadow over artisanal diamond mining in general. There is little disputing that alluvial diamonds have fuelled episodes of civil violence in each of these countries but policymakers and donors have done very little to help the industry shed its negative image. In the case of Liberia, there was a golden opportunity to 'rebrand' the sector in the PRSP - specifically, to clarify its economic importance to rural Liberians, and how if promoted effectively, it could alleviate poverty countrywide. The document, however, does little to disassociate the country's alluvial diamond mining sector 


\section{'Grow What You Eat, Eat What You Grow': Rural Livelihood Diversification in Bomi County}

This section of the paper reports findings from pilot research carried out in the villages of Bonga and Sackie Town near Tubmanburg in Bomi County (Figure 2). In total, 30 heads (all male) of farming-mining families were interviewed, their selection purposive, with the intention of capturing a range of qualitative data. ${ }^{5}$ The size of the families of each individual interviewed ranged between five and 10 people; in many cases, household heads reported having more than one wife. The data retrieved from these interviews have helped to cast light on the dynamics of the pattern of livelihood diversification emerging in Tubmanburg and surrounding localities. Specifically, these interviews unearthed details of the linkages between semi-subsistence rice farming and artisanal diamond mining in Bonga and Sackie Town, a more nuanced understanding of which could prove integral in the fight against poverty in rural Liberia.

According to the latest census (Government of Liberia, 2008), Tubmanburg's population stands at 13,114. Bomi County itself is sparsely populated, the 2008 census placing the population at 82,036 , although this is approximately 15 percent higher than the figure $(66,420)$ obtained on the last national census undertaken pre-war (1984). Tubmanburg, which is located only 50 miles from the country capital of Monrovia, was a strategic rebel stronghold during the war, largely because of its rich diamond reserves. This led the United Nations to establish an office in the heart of the town, as part of an effort initiated at the conclusion of the 


\section{Poverty and Reintegration in Tubmanburg}

Before reporting findings on the livelihood dynamics in Tubmanburg, it is instructive to first provide an overview of the demographics of the locality itself, and the research strategy adopted. During interviews, discussions focusing on ethnic origin were deliberately avoided. With ethnicity playing such an important role in the country's debilitating civil war and indeed, its development, it was determined that questions centring on, inter alia, tribe and birthplace could have been taken out of context, and were therefore not asked. Bomi County is a 'melting pot' of cultures, with representation from all sixteen of Liberia's main ethnic groups. ${ }^{7}$ All thirty individuals interviewed mentioned being native to the Tubmanburg area or having resided there for an extended period prior to the war. Despite being an issue that is beyond the scope of the present paper, the analysis would benefit from a brief discussion on the 'reintegration' of these, and other, people, into the county.

A reviewer of this paper, however, requested that the issue be given significant attention:

'The issue of access to land is crucial to this discussion and is alluded to; however, what we are not told is: how the land tenure system operates (there is mention of chiefly authority but not in relation to land); how land is apportioned for mining and farming if there is conflict between the two; and if "rent" of diamond mining land is a feature in this area as elsewhere in Africa where informal mining takes place'.

It is impossible, however, to address all of these requests in their entirety. As Unruh (2009) explains, an already-ambiguous land tenure problem was complicated even further by the war, during which mass theft, loss, looting and destruction of deeds took place. Having no registry in land has meant that no record system exists that can be used to identify the rightful owner of land. Today, over 75 percent of cases in Liberia's statutory courts are land and property-related. 
Each of the 30 people interviewed indicated that they were the rightful owners of the lands on which they were cultivating rice and mining. But the Liberian Government owns and administers all public lands, on which rural indigenous communities are permitted to maintain lineage-based communal tenure. Throughout the post-war period, the chiefs have been heavily relied upon to broker what have become exceptionally difficult land transactions. According to the law, all lands in a designated indigenous area are under the control of the chief, who has a communal deed to tribal areas and is empowered to administer their distribution. Although Liberia's chiefs enjoyed similar powers before the civil war, the procedure required to obtain land seemed much more straightforward. Prospective landholders were first required to obtain a Tribal Certificate, which granted the consent of the local tribal authorities, including the Paramount Chief, Clan Chief and elders. To secure this, a payment was made - typically in cash - after which the grant needed to be endorsed by the president and registered with the courts in Monrovia. The procedure, explains Clapham (1976, p. 114), made it possible 'for any Liberian to buy land, regardless of his place or community of origin'. A relatively straightforward policy of land acquisition provided the bedrock for a vibrant three-pronged agricultural sector: a) foreign concessionaires, the classic example being the rubber plot controlled by the Firestone Company; b) Liberian-owned commercial farmers - principally large-scale, indigenously-controlled rice farms; and c) smallholders, who, in the mid1970s, controlled more than 90 percent of agricultural holdings (after World Bank, 1975). It is largely an eroded version of this 'structure' that Liberians attempted to re-enter upon their return to the country they had fled during the civil war.

In localities such as Tubmanburg, chiefs have proved integral in facilitating the reintegration process because of the overabundance of squatters. As Richards and Chauveau (2007, p. 25) explain, 'during the civil war several of these large plantations attracted armed factions' and consequently, 'plantations compounds held out prospects of accommodation, facilities (water, electricity, communications equipment) and loot (vehicles, etc.)'. Many of the lands abandoned by fleeing citizens are now fully occupied by squatters. Rincon (2010) presents a case in Ganta City in Nimba County, which illustrates how squatters have complicated the reintegration process:

'When the civil war ended in late 2003...Slowly, the civilians started to return to Nimba County, but many were unable to reoccupy their homes and land, which had been taken over by squatters...One particular group of squatters is constituted by young fighters from pro-Taylor militias who fought and won the battle over Gama. When the war ended, these young fighters used their physical presence and position...to appropriate land...Thus the picture that emerges is that of a complex process of land grabbing and appropriation by ex-fighters who feel a right to settle in Ganta because they, in their own words, "defended the land". [p. 16] 
In such cases, squatters can claims rights to property through the law of adverse possession, according to which, individuals can legitimately claim land after 20 years of occupation provided that there has been no attempt by the property owner to evict (World Bank, 2008). ${ }^{8}$

As is the case with most towns across Liberia, in Tubmanburg, the land ownership situation is unclear. As noted, all interviewees reported having resided in the vicinity of the town for extended periods prior to the war. This, it was assumed, factored heavily in the decisions of the chief and Liberian authorities concerning the entitlement of these individuals to occupy lands in Bonga and Sackie Town. In other parts of the country, such as Lofa Bridge and Weassua, to avoid long-term complications, many returnees who are the rightful owners of lands occupied by migratory groups have elected to broker financial agreements with squatters, jointly engaging in economic activities such as farming or mining and sharing whatever profits are earned. What was apparent, however, was that each of the 30 interviewees was poor: their agricultural harvests are insufficient to generate the disposable incomes needed to cover a range of family expenses, including fuel, children's school fees and livestock. The sections that follow will detail how these people are positioning themselves to escape this hardship.

Seizing an Opportunity

A market flooded with imported American foodstuffs has motivated rural Liberian families to turn their attentions to growing their own rice crop. These harvests are being used to support an artisanal diamond mining cycle that could potentially generate significant financial returns. Many of those who have exhausted their supplies of rice originating from their plots have opted to purchase to feed their families, inter alia, cheap American-manufactured spaghettis, macaroni and sauces, as opposed to more expensive imported rice consumed by the household. Along the Tubmanburg High Street, there are numerous shops selling these products.

Most of the elderly people who have returned to farm rice in Bonga Village and Sackie Town are 'seasoned' farmers. Even many of the township's middle-aged residents, who had fled the country before the war, have likely had few troubles re-entering a life of farming because of the training they received under the rule of President Samuel Doe (1986-1990):

'The the 1980s, all public schools required students to take a vocational class in farming. Students spent one afternoon per week cultivating a school-owned vegetable garden, learning the basic principles of agriculture and sharing equally the produce they cultivated' [USAID, 2010, p. 28] 
Rural families in Tubmanburg and surrounding areas have no illusions about what rice farming can deliver, economically. Those interviewed were in agreement that a shortage of labour, seeds, financial capital and pesticides confine smallholder rice production to a semi-subsistence level, in turn increasing dependence on supplies of imported product (after Tsimpo and Woden, 2008).

What little supply of rice is harvested, however, is prized in both Sackie Town and Bonga village. It has enabled many of smallholders to 'hire' a team of workers - generally between five and ten youth - to wash gravels for diamonds. Every day, landowners give each hired mine labourer one cup of rice and a 'Maggi Cube' (soup cube), which is mixed together with some fish and consumed for lunch. Whatever diamonds are recovered are then sold, and the winnings shared 50:50 between the farmer and the team of workers. The movement of Tubmanburg's rural farm households into artisanal diamond mining is an illustrative example of what the literature refers to as 'distress-push' livelihood diversification (Barrett et al., 2001): the idea that changes which yield supplementary income are necessary for a family's survival. Villagers interviewed in Tubmanburg indicated as much - that moving into artisanal diamond mining was very much a survival strategy, although these days, due to depleting near-surface reserves, this appears to be less so in Sackie Town, where there are currently 75 subsistence farms. As one male household head explained, 'everyone [here] is farming' and that because of the shortage of accessible stones, there are 'only 10 local miners here [in Sackie Town]... [who] don't have [many] materials to work with' and use their 'own local mining with tools', principally shovels purchased in Monrovia.

The impression conveyed was that artisanal diamond mining would be pursued far more proactively if labour was more widely available. As another household head explained, 'many people don't have the money [to mine] and even the few who do don't have the workers'. This could explain the disproportionate gender balance and the abundance of young people present in Sackie Town: according to the latest census, there are 478 children, 329 women and 175 men. Most of the household heads interviewed in the village reported having two wives and each had at least four children; all indicated that their boys and girls work on the family farm, the latter, often at the expense of a school education. The village's families work diligently to generate enough surpluses of peppers, cassava and most importantly, rice, to trade with merchants from Monrovia, who arrive with household goods for sale every Tuesday (the village's market day). For household heads, putting the family to work on the farm eliminates labour costs, and has proved to be an effective strategy in times of hardship: at a minimum, families are producing sufficient food supply to satisfy their own needs. 
All indications point to both farming and artisanal diamond mining being fairly well-integrated into robust year-long cycles at both sites, the former undertaken during the rainy season and the latter in the dry season. During interviews with household heads in both villages, it was explained that during the dry season, diamondiferous ore is 'sorted' in anticipation of the rains, when stones can easily be separated from uneconomic alluvial gravels. During visits to a number of mine sites, labourers were seen stacking piles of ore alongside river banks in preparation for the rains. One household head, 'Mr. Konneh', supplied details of the year-long cycle of the typical Tubmanburg household. Mr Konneh, his two wives and eight children work year-round, harvesting cassava and rice, selling surpluses at the local market in Sackie Town every Tuesday. As is the case with most residents, rice is the primary focus of his household agriculturally, picked in September following 10 months of preparation: 'brushed' in October and November; burned in March, following a three month 'rest'; 'squashed' in April and May'; and 'grown' in June. Mr. Konneh explained that when 'all goes well' with diamond mining, which is undertaken concurrently with the preparation of rice fields during the dry season, his wives take over the farm work.

The literature identifies seasonality as an example of 'demand-pull' diversification: the idea that households do not necessarily 'branch out' into nonfarm activities because of necessity but rather do so because of it is anticipated that there are financial rewards in doing so (after Barrett et al., 2001). The patterns of seasonality in both Sackie Town and Bonga Village, however, are by no means associated with entrepreneurial behaviour and are therefore not an example of 'demand-pull' diversification in the conventional sense. It is, rather, poverty that has given rise to this regimented way of rural life based around seasons, any deviation from which could be detrimental to the wellbeing of the household. This pattern of seasonality, which again, can be seen as a coping strategy given the very difficult circumstances faced by the township's rural households, is a mirror image of what has unfolded in neighbouring Sierra Leone, where, as Maconachie and Binns (2007, p. 372) report, in the early-1970s, across Eastern Province 'diamond mining and farming activities "dovetailed", with mining being undertaken in the dry season when river levels are low, whilst farming was the dominant activity during the rainy season'. Despite Sierra Leone's decade-long civil war, this pattern remains very much intact today.

This raises questions about the origins of the livelihood diversification occurring in rural Liberia. The evidence points to many household heads having been heavily active in diamond mining before the war. Mr. Konneh, for example, indicated that he secured a mining claim at 'Small Creek' in 1987, started mining in 1988, hired numerous workers to wash gravels, and sold all of his diamonds to a Malian broker named Bashiro. In 
Seizing of an Opportunity II

2002, when LURD9 ${ }^{9}$ rebels arrived in his village, he fled to Monrovia but returned in 2005, when he started farming rice and eventually, resumed work at 'Small Creek' with his team of four labourers.

Other interviewees, such as 'Mr Flomo', reported having an even longer mining history. Mr. Flomo indicated that he has been mining since 1971, citing that the 'reason why I like mining is I want to get plenty of money to do [things]'. He currently has four mining claims in Sackie Town, and another two in Bopolu County. He worked and resided in Bopolu up until 1988, at which time he moved to Tubmanburg. In 1992, Mr. Flomo fled to Côte D'Ivoire but returned to Sackie Town in 2001, where, in addition to establishing a rice farm, he attempted to forge an investment deal with an Italian man named Colombo. 'Mohammed Traoré', a naturalized Liberian who arrived in the country in 1966, reported much of the same, indicating that he had obtained a mining claim in 1987 but has failed to renew it. Mr. Traoré reported that, in an effort to secure monies to renew his lease, he worked in Kombo as a mine labourer but fled when Charles Taylor seized power. He sought refuge in neighbouring Sierra Leone, where he stayed until 1992, and when he returned, began farming cassava and rice, and has recently used the harvest to help reinvigorate his diamond mining activities.

These findings imply that, in both Sackie Town and Bonga Village, the interlocked nature of diamond mining and farming is very much a pre-war phenomenon. This particular pattern of livelihood diversification has proved sufficiently robust, the lengthy episodes of civil violence failing to dissuade people from returning to what they know. Perhaps most importantly, for rural households in both villages, a diversified livelihood portfolio comprised of diamond mining and farming has proved to be an important buffer against income poverty. The war certainly raised the profile of diamond mining in Liberia considerably, providing a badlyneeded opportunity for returnees to improve their livelihoods.

The aforementioned livelihood diversification could not happen, however, if local government officers did not also derive some benefit from allowing it to unfold. A main target identified under 'Economic Revitalization', one of four 'pillars' in the Liberian PRSP, is to improve transparency in the country's diamond mining economy; in fact, the impression conveyed is that the sector will be a part of the revitalization effort. But whether the measures put in place to improve its governance have actually reduced corruption is open to debate. The establishment of a National Diamond Task Force to implement the Kimberley Process Certification Scheme (KPCS $)^{10}$ has helped to generate a much-needed trail of paperwork but it has also spawned diamond 
mining regulations and policies that have done little to address concerns in the areas where rough stones are being sourced.

One such concern is the woefully under-resourced local government offices scattered across the country. Each has a range of responsibilities, including having to 'track' and record diamond production, and regulate mining activities. Concerns over the ability of the Ministry of Lands, Mines and Energy's (MLME) mineral inspection agents to enforce regulations were first voiced in a United Nations Security Council report in 2005 (UN, 2005). It states: 'while the Panel commends the efforts of the Ministry of Lands, Mines and Energy in respect of those training initiatives, it remains concerned by the lack of funding required to place those personnel on the payroll and successfully deploy them to the field' (p. 4). Evidently, the Liberian Government addressed these regulatory inadequacies to the satisfaction of the United Nations because the country became a member of the Kimberley Process in 2007. The evidence from Tubmanburg suggests that the 48 mineral inspectors currently in place countrywide to enforce the KPCS are not fully supported. This is likely contributing to the weak enforcement of the KPCS because there is little incentive for mineral inspectors to do their jobs. In Tubmanburg, inspectors have jumped at the opportunity to extract monies from local populations in exchange for turning a blind eye on unlicensed artisanal diamond mining activities. These bribes or 'dashes', though relatively small, are nourishing a pattern of livelihood diversification that is central to the survival of hundreds of rural families.

Under the government of warlord-turned-president Charles Taylor, the Minerals and Mining Law was implemented. It was approved by the senate, House of Representatives and Taylor himself in April 2000 and came into force in September of that year. As detailed by Elder (2002), the law established three types of mining licenses: 1) the Class $C$ mining license, which may only be granted to Liberian citizens, is valid for one year but can be renewed annually, and covers no more than 25 acres; 2) the Class $B$ mining license, which is also only open to Liberians, is valid for five years with the option of further five year renewals but unlike the Class $C$ option, authorizes holders to use industrial processes (machines); and 3) the Class $A$ license, which is open to all citizens, may be granted to the holder of an exploration license, can be issued for an area of up to $1000 \mathrm{~km}^{2}$, and is good for a period of 25 years with the option of further 25 -year renewal periods. The restrictions attached to the Class $C$ license - namely, a requirement that holders not use 'large-scale, heavy duty or earth moving equipment', and the costs involved with securing it - have proved crippling for Liberians: prospective license holders are confined to engaging in laborious but slow manual methods during the dry season, and have experienced considerable difficulty securing their papers. The one option available to the few 
people who have managed to secure a Class $C$ license is to try and mobilize the US $\$ 5000$ needed to 'graduate' to a Class $B$ license - a move which, for a party with few funds or international connections, is near-impossible.

For parties wishing to secure a Class $C$ license, the process is rarely straightforward, requiring several visits by prospective applicants to the MLME and payment of innumerable bribes to even get an application assessed - a laborious exercise that is both time consuming and ends up costing more than it should. This point was raised by the Secretary of the Federation of Miners Association of Liberia during an interview:

'[The] license fee is exorbitant - to acquire the licensing takes a lot of time. Starts off at district, travel to Monrovia, Ministry of Mines...survey fee, transportation, ID card...people grow frustrated. The faster nickel is better than the slow dime'.

The inability of Liberians to mobilize the funds to cover the US\$150 registration fee and the US\$150 'demarcation' fee for a Class $C$ license has created an opportunity for local mineral inspectors, who permit mining to take place for short periods in exchange for nominal payments. This has happened in Tubmanburg, where villagers such as Mr. Konneh and Mr. Flomo who are not in possession of a Class $C$ license, were permitted to mine by the local mineral inspector, following payment of US\$30-50 and a promise that the finances for the license and demarcation fee will be paid within a reasonable time. Typically, people are given two-three months to mobilize these monies but few manage to do so, which leads to another round of US\$30-50 payments and the start of another two-three month cycle.

Mineral inspectors have willingly accepted these 'dashes' because of their own economic situations. Despite being charged with monitoring illegal mining activities and providing timely reports to Monrovia on the state of diamond digging in their districts, inspectors are paid less than US\$70 monthly and required to pay for their own transport to mine sites and ministry headquarters whenever a meeting takes place. Interestingly, the problem seems to be recognized by officers in Monrovia:

'If I don't have a vehicle to monitor Monrovia...the people under me don't have bicycles...Our mining agents are human, and the incentives are meagre, so they compromise with the illegal miners. So we also have to look at the incentives for the inspectors, so if someone is sent there, they have to pay himself, lodge there for a week. So if there is someone who discovers a diamond, then he can just bribe to guy'. [Interview, senior government officer, Monrovia]

Although the scale of the bribery itself is of little concern, the level of responsibility being given to mineral inspectors is worrying. Again, their job is to inform the minister about boundary disputes, illegal mining activities, the status of licenses, and, most importantly, whether plans for licensed mining activities are targeting an appropriate place. But as one senior official admitted in an interview, 'sometimes I cannot verify the report 
from them, can't get to them... [so] they bring a report but...' Given the level of financial remuneration being provided to inspectors, the delays with paying their salaries, and the expectation that they will cover all of their expenses for field inspections, not surprisingly, few visit mine sites and are therefore potentially supplying Monrovia with inaccurate information.

Whilst acknowledging this problem, it is unlikely that officials in Monrovia will address it. At present, there is considerable preoccupation at the highest policymaking levels over 'missing' diamonds. At the time of writing, the Ministry was unable to account for over 9000 carats of diamonds, ${ }^{11}$ which could threaten Liberia's KPCS membership. This distraction bodes well for both mineral inspectors and rural Liberians because there is little threat of their ongoing 'arrangements' being 'discovered'.

Perspectives on 'Diamond Mining, Rice Farming and a "Maggi Cube",

The lives families in both Sackie Town and Bonga Village have re-entered are quite fragile, based around artisanal diamond mining, semi-subsistence rice (and occasionally, supplementary cassava) farming and 'Maggi Cubes'. As interviewed household heads revealed, rice is harvested on family plots and used to feed workers who are hired to dig for diamonds. Each is given one-two cups of rice and a 'Maggi Cube', and whatever stones are recovered are distributed (typically 50:50) amongst family heads and hired hands. Whilst this way of life, which is increasingly becoming the norm in Tubmanburg, is not generating much finance, it has proved to be an effective survival strategy in what are very difficult living conditions.

Household heads consulted in Sackie Town and Bonga Village seemed satisfied with the current setup in large part because it is an effective buffer against outright starvation. The ability, in the worst of cases, to satisfy the food requirements of the household is indeed a luxury in an environment where impacts of aid are have been minimal and which is devoid of even the most basic of facilities. In Bonga Village, there are no schools, medical facilities or water pumps, and whilst there is a small health clinic in Sackie Town ('Sackie Town Clinic'), it has no drugs. The methods used to mine diamonds in both villages are manual and inefficient, and therefore unlikely to yield much in the way of returns. But importantly, current labour arrangements provide households with a lifeline: households can fall back on agriculture and substitute rice with more inexpensive imported foodstuffs such as spaghetti, whilst patiently searching for a potentially life-changing diamond discovery, however improbable it may be. The case of 'Sando Freeman', a resident of Bonga Village, is one of numerous illustrative examples of this attitude. Mr. Freeman explained during an interview that he got 
involved in mining because 'it is the best way to sustain [himself] and [his] family'. Prior to 1997, however, he was farming, and therefore 'never cared at the time about mining'. He furthermore explained that, when he does not have any diamonds and does not have money, he 'will just do farming', stating that 'even when I don't get money, I get food for the family', consuming the rice from his farm, and selling the gari he processes from his cassava patch. Similarly, 'Mohammed Traoré', who is also a resident of Bonga Village, explained that after mine work 'became difficult', he 'jumped back into farming business'. Most of the other household heads consulted seemed appreciative that when times are difficult, they are able to subsist off of their own crops.

Hope seems to be the prevailing theme in both villages, the regimented lifestyles of households epitomizing the most monumental of struggles. Residents seem willing to subject themselves to such difficult lifestyles because they genuinely believe - as unlikely as it may seem - that they will one day discover diamond riches which will change their situations forever; peoples' hopes and dreams are made possible by the local mineral inspector, who again, in exchange for a nominal fee, allows people to continue engaging in what appears to be an exercise in futility. Mr. Freeman explained that 'every year, [he] has to go to the mining agent and give money in order to mine', which typically amounts a payments of US\$50 every three months. His entire life seems to revolve around making these payments: he sells his gari, a bag of which fetches US $\$ 18$, for the sole purpose of covering these payments, although he professes that 'US\$50 is too much for poor people in the bush'. Mr. Konneh's circumstances are slightly different. He claimed to be 'trying hard to earn money to pay for license', and not being concerned about potential government persecution because he had already been awarded a mining license at one point, noting that 'if I get gravel, I can definitely go for and get a license because I have an old license'. Another resident of Bonga Village, Mr. 'Alpha Conteh', has adopted a similar strategy. Mr. Conteh pays local mineral inspectors small sums of money, believing that his expired Class $C$ license has value. He employs 35 workers and a supervisor to wash gravels on his plot, driven by the belief that 'one stone that comes can carry you far off'.

What is the government's view on these dynamics? The rural inhabitants interviewed in both Sackie Town and Bonga Village sense some sympathy on the part of the government towards their illegal mining activities. As Mr. Kommey confidently put it, 'even if the license expires, government is lenient, even after few months after expiration, they will be fine'. Consultations with government officers suggested much of the same. Most seemed oblivious to the situation that has unfolded on the ground but sympathized with rural peoples' struggles. The local government officers interviewed seemed particularly understanding. During one interview in Harmon Hill in Tubmanburg, an officer posed the question: 'Many of these people don't have the money to 
eat, so how can they pay to process the documents?' Again, this seems to be the view at all levels of government, including senior officials, especially those based at the MLME. The testimonial of one officer was particularly revealing:

'How can you dispossess these communities? Can you expect them to come to Monrovia? In Wesua, people don't even have farms. They mine diamonds and come to Monrovia to buy peppers'. [Senior officer, MLME]

But despite the rhetoric, changes capable of having a more lasting and meaningful impact on peoples' lives have yet to materialize.

The government's laissez-faire attitude towards licensing may, however, may prove helpful over the long term. First, and perhaps most significantly, its local government officers have gained the trust of diamond diggers. With as many as 70 percent of Liberia's diamonds being smuggled across its porous borders, these relations could prove instrumental in helping to buffer against smuggling. Whilst Tubmanburg is fairly centrally located, the positive views villagers have toward mineral inspectors has undoubtedly helped to ensure that excavated stones being transported to Monrovia for inspection and exported through legitimate channels. Second, the informal diamond mining now widespread in Liberian towns such as Tubmanburg has helped to unify rural societies. As one government official in Tubmanburg explained, 'in theory, 97 percent of Liberians don't have to have a deed but in reality, no one can mine land without permission or negotiations with landowners and local authorities'. It was explained that even though Class $C$ licenses are rarely issued, a prospective miner must still go through the necessary steps before mining: consulting the paramount chief, the town chief or clan leader, and where applicable, the mayor. Traditional custom requires miners to obtain permission to, inter alia, use water and local toilet facilities.

It is important, however, not to lose sight of what these dynamics are: households' coping strategies in a challenging economic environment. In Tubmanburg, the stalls flooded with imported rice have stiffened the competition with, and diminished the agricultural prospects considerably for, local rural households. But this is not to say that the locality's farmers have not put their rice crop to good use. As explained, many have used the rice they have to feed workers hired to dig for diamonds on their plots. Artisanal diamond mining offers one of few routes out of poverty in rural Liberia - a country where donor efforts have yet to have a significant impact on the poor. 


\section{Concluding Remarks}

'Grow What You Eat, Eat What You Grow' has fast become the catchphrase for survival in rural Liberia. The country today is a landscape of deteriorated farmlands and markets flooded with imported American-produced foodstuffs, notably rice. With farm support still in short supply, scores of rural families are now intensifying efforts to produce their own rice not only for personal consumption but also as 'payment' to hired diamond mine labourers. Specifically, semi-subsistence harvests have enabled farm families to lure gangs of labourers hired specifically to mine diamonds from plots, as illustrated by findings from pilot research conducted in the villages of Bonga and Sackie Town in Bomi Country. They are 'fed' and all stones discovered are divided evenly between the workers and the household head.

The findings from this pilot analysis raise two important questions for further research. First, there is the question of whether a rural poverty alleviation strategy that emphasizes smallholder development is the best way forward in Liberia? In the absence of notable domestic rice production, a fairly impenetrable market populated by imported foodstuffs has emerged. Even if this trade network could be dismantled and domestic producers reintegrated, how far can an economy based on smallholder production move beyond subsistence output? Experiences elsewhere in West Africa capture the limitations of a small-farm first approach in established agricultural economies (see Banchirigah and Hilson, 2010). Agriculturally, the goal should be to help resettled families become more self-sufficient and nothing more. As shown in an old World Bank report (World Bank, 1975), even during the 1960s and 1970s, times when smallholder farming was well-connected to local markets, the industry's incomes were low. It reports that the average income of the traditional smallholder is about $\$ 70$ per capita, compared with a national average of about $\$ 250$ ', chiefly because 'the traditional sector is largely outside the monetized economy, located in areas with minimal infrastructure' (p. 4).

Given the obvious limitations of smallholder farming as an economic enterprise, specifically, its inability to satisfy the economic needs of rural households on its own, greater attention must be paid to promoting nonfarm activities capable of generating supplementary incomes. This raises a second question: can artisanal diamond mining be one of these activities? Policymakers and donors are sceptical about promoting artisanal diamond mining because of its role in the country's civil war. But with mounting concerns over a lack of employment potentially sparking further violence, perhaps a 'rebranded' artisanal diamond sector could alleviate significant rural poverty. Officers at UNMIL are beginning to voice concerns over a potential lack of employment: 
'With few formal sector jobs available and returns from informal sector work low, job creation is a top priority. Increased access to decent and productive employment will also be a critical means of sustaining the peace...' [UN, 2008, p. 11]

This peace, explained the head of the integration, rehabilitation and recovery arm of the UN Mission in Liberia, is contingent upon mobilizing the youth because if 'they [the youth] have an alternative, they do not fight' (Ibid).

Supporting the livelihood diversification strategy unfolding in localities such as Tubmanburg would go a long way toward mobilizing the youth, alleviating poverty and quashing concerns over recurring violence. The adjustments scores of families in villages such as Bonga and Sackie Town have made to position themselves to benefit from untapped diamond wealth have been nothing short of remarkable. These efforts should be supported because they could prove integral to breaking rural Liberia out of its poverty trap.

\section{Acknowledgements}

This paper is a critical output of Egmont's 'Artisanal Diamond Mining Project', funded by the Belgian Government. The authors would like to thanks the editor and two anonymous reviewers of the journal for their constructive criticism on a previous draft. Needless to say, any errors this article may contain are the sole responsibility of the authors. 


\section{References}

Banchirigah, S.M., Hilson, G. 2010. De-Agrarianization, Re-Agrarianization and Local Economic Development: Re-Orientating Livelihoods in African Artisanal Mining Communities. Policy Sciences 43(2): 157-180.

Barrett, C.B., Reardon, T., Webb, P. 2001. Nonfarm income diversification and household livelihood strategies in rural Africa: Concepts, dynamics, and policy implications. Food Policy 26(4): 315-331

Bryceson, D.F. 1996. Deagrarianization and rural employment in sub-Saharan Africa: A sectoral perspective. World Development 24(1):97-111.

Clapham, C. 1976. Liberia and Sierra Leone: An Essay in Comparative Politics. Cambridge University Press, London.

Elder, T. 2002. Mineral legislation of Liberia. Applied Earth Science: IMM Transactions B 111(3): 200-203.

Ellis, F. 1998. Survey article: Household strategies and rural livelihood diversification. The Journal of Development Studies 35 (1):1-38.

Ellis, F. 2006. Agrarian change and rising vulnerability in rural sub-Saharan Africa. New Political Economy 11(3): 387-397.

Fanou, R.W., Koiwou, T.D. 2009. Liberia, Country Presentation. Paper presented at the Technical Consultative Meeting on the 2008/2009 Ex-Post and the 2009/2010 Cereal and Food Balance Sheet of CILSS and ECOWAS Countries, Accra 4-6 November.

Government of Liberia. 2008. Government of the Republic of Liberia: 2008 National Population and Housing Census Preliminary Results. Government of Liberia, Monrovia.

Government of Liberia. 2009. Bomi County Developmental Agenda. Government of Liberia, Monrovia.

International Monetary Fund (IMF). 2008. Poverty Reduction Strategy Paper: Republic of Liberia. International Monetary Fund, Washington DC.

Maconachie, R., Binns, T. 2007. 'Farming miners' or 'mining farmers'?: Diamond mining and rural development in post-conflict Sierra Leone. Journal of Rural Studies 23: 367-380.

Ministry of Agriculture (MoA). 2007. Comprehensive Assessment of the Agricultural Sector. Ministry of Agriculture, Liberia.

Richards, P., Chauveau, J.P. 2007. Land, Agricultural Change and Conflict in West Africa: Regional Issues from Sierra Leone, Liberia and Côte D'Ivoire. CSAO, Paris.

Rincon, J.M. 2010. Ex-combatants, Returnees, Land and Conflict in Liberia. DIIS Working Paper 2010:05, Danish Institute for International Studies, Copenhagen.

Sirleaf, E.J. 2010. The Role of Agriculture in Post-Conflict Recovery: The Case of Liberia, paper presented at The Symposium on Global Agriculture and Food Security, Mayflower Renaissance Hotel, Monrovia, 20 May 2010.

Tsimpo, C., Wodon, Q.Y. 2008. Rice Prices and Poverty in Liberia. World Bank Policy Research Working Paper, World Bank, Washington DC.

United Nations (UN). 2005. Letter dated 16 March 2005 from the Chairman of the Security Council Committee established pursuant to resolution 1521 (2003) concerning Liberia addressed to the President of the Security Council. United Nations, New York. 
United Nations (UN). 2008. United Nations Development Assistance Framework Liberia 2008-2012. United Nations, New York.

United Nations (UN). 2009. Overcoming Barriers: Human Mobility and Development. United Nations Human Development Report, United Nations, New York.

United Nations (UN). 2010a. Findings: Liberia Household Food Security and Nutritional Surveillance. United Nations Mission to Liberia, Monrovia.

United Nations (UN). 2010b. Sixty-forth Session Fifth Committee Agenda Item 146Administrative and Budgetary Aspects of the Financing of the United Nations Peacekeeing Operations. United Nations, New York City.

Unroh, J. D. 2009. Land rights in postwar Liberia: The volatile part of the peace process. Land Use Policy 26: 425-433.

USAID. 2009. Global Food Security Response: Liberia Rice Value Chain Analysis Report. USAID, Washington DC.

USAID. 2010. Feed the Future - Liberia FY 2010 Implementation Plan. USAID, Washington DC.

World Bank. 1975. Report and Recommendation of the President to the Executive Directors on a Proposed Credit to the Republic of Liberia for a Lofa County Agricultural Project. Report No. P-1671-LBR, International Development Association, Washington DC.

World Bank. 2008. Insecurity of Land Tenure, Land Law and Registration in Liberia. Report 46134-LR, World Bank, Washington DC.

\section{Notes}

\footnotetext{
1 'Liberians Drop Rice for Spaghetti’ http://news.bbc.co.uk/1/hi/world/africa/7360649.stm (Accessed 03 October 2010).

${ }^{2}$ The IMF and World Bank require member countries to produce a PRSP before it can qualify for debt relief or funding.

${ }^{3}$ http://www.reliefweb.int/rw/rwb.nsf/db900SID/SNAA-7TT3MF?OpenDocument (Accessed 31 August 2010).

${ }^{4}$ http://www.reliefweb.int/rw/rwb.nsf/db900SID/SNAA-7TT3MF?OpenDocument (Accessed 31 August 2010).

${ }^{5}$ In addition to the 30 family heads in both villages, six local government officials, and two officers from the Federation of Miners Association of Liberia were interviewed. The findings reported in this section of the paper are drawn, verbatim, from these interviews. All respondents were anonymized,

${ }^{6} 6$ http://www.un.org/apps/news/storyAr.asp?NewsID=22430\&Cr=liberia\&Cr1= (Accessed 5 September 2010).

${ }^{7}$ These are the Dey, Gola, Gbandi, Kissi, Gio, Vai, Kpelle, Mende, Bassa, Gbee, Kru, Krahn, Mandingo, Sapo and Loma.

${ }^{8}$ In Monrovia, the issue of whether the 14-year civil war period should be counted towards the 20-year adverse possession period is being discussed. The concern is that, if a formal decision is made that proves unfavourable to squatters, with little to lose, many will do whatever necessary to retain lands or secure some form of compensation.

${ }^{9}$ The Liberians United for Reconciliation and Democracy (LURD) was a rebel group active between 1999 and 2003.

${ }^{10}$ The Kimberley Process Certification Scheme (KPCS) is a joint government, civil society, and industry initiative aimed at stemming the flow of rough diamonds used to finance wars.

${ }^{11}$ http://allafrica.com/stories/201004220344.html (Accessed 4 October 2010).
} 
Figure 1: 'Grow What You Eat, Eat What You Grow' sign in Tubmanburg

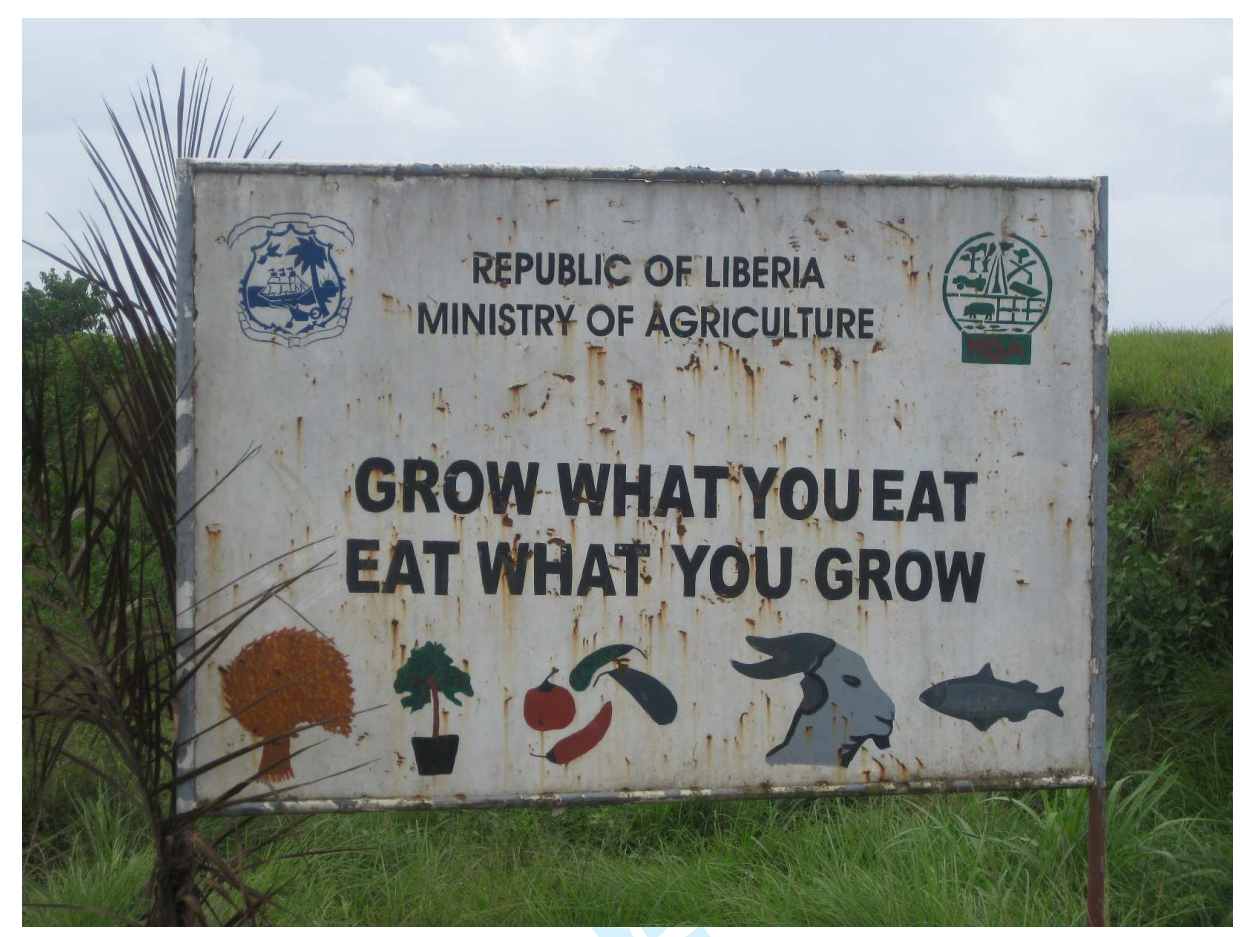


Figure 2: Location of Tubmanburg, Liberia

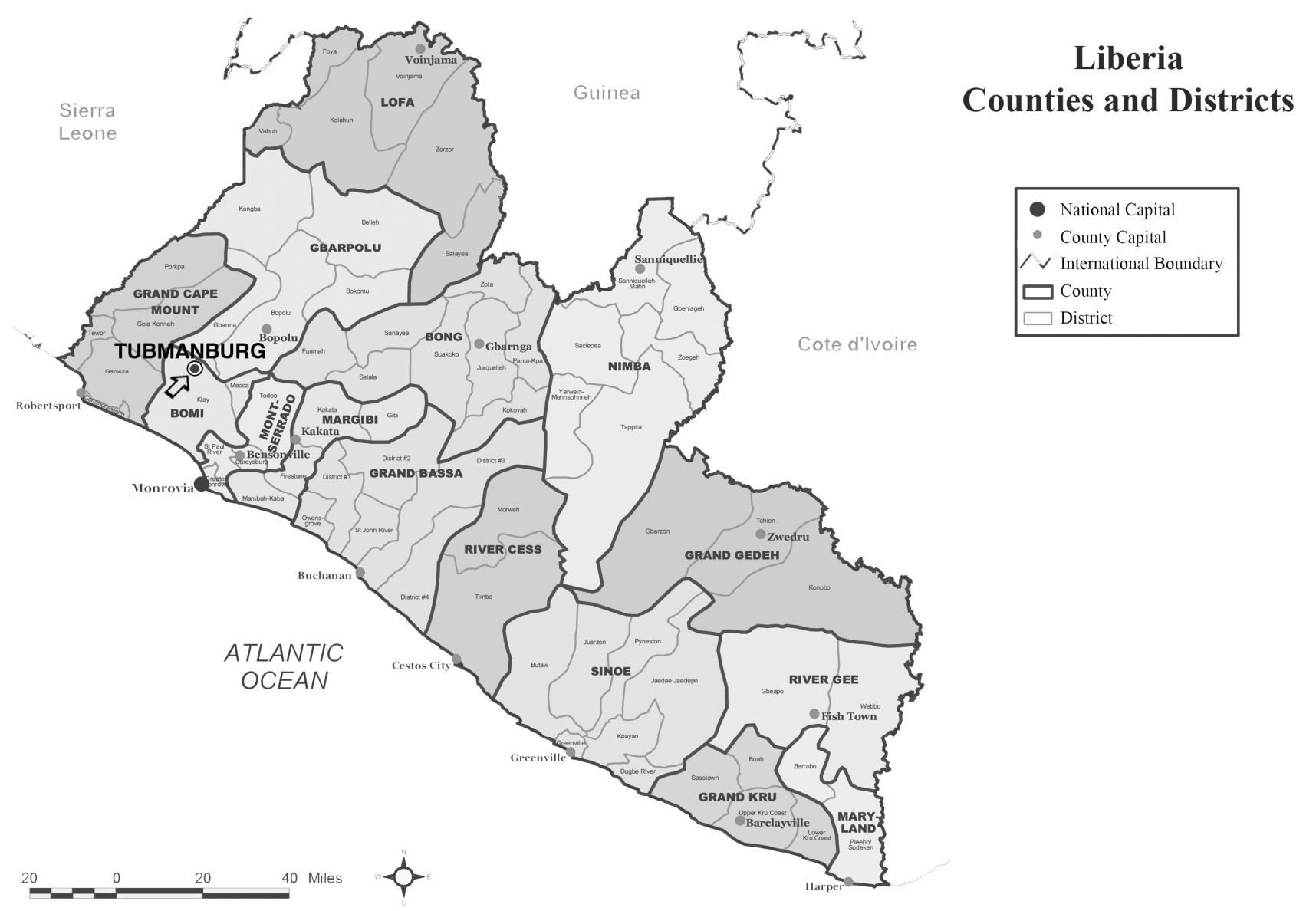

Source: Adapted from UN, 2008 
Responses to comments

The primary data is not strong or not used to its full extent. There are a series of arguments made but these are not clearly elaborated or linked to the overall narrative. As a result, what the readers can learn for certain from the paper, is not really groundbreaking knowledge. All the material brought forward should support the main argument and findings, so a much clearer focus is needed.

We believe that the data is strong and that it does support the main arguments. To make the analysis a bit more clear, however, we have provided more detail on who was interviewed, and made arguments more clear.

- P.3 "they have rather adopted a unique livelihood strategy..." I doubt if it is as unique as is claimed.

We have removed the word 'unique', although these dynamics are unique, hence the paper.

- P.3 "... artisanal diamond mining is one of the routes out of poverty". For who, these big farmers who were interviewed or the miners who survive on a cup of rice a day and the distant hope of finding a good stone? These are not 'big farmers' by any means. The land ownership situation is quite tenuous in Liberia, and we have included a section on Page 8 which explains this more. We have also provided more background on the people interviewed, which shows that they are, in fact, poor.

- P.3 "... to alleviate their hardships" It is important to point out that the "improved position" refers to the position of the farmers/landowners, rather than to that of the miners, who receive wages on which they can hardly survive.

Good point. Yes, this is made clear.

- P.3 "... for markets but rather for subsistence" I would prefer "semi-subsistence"

This is done.

- P.4 " most continue to champion a policy..." which is rather relevant in non-diamond areas (the majority of counties in Liberia do not have diamond deposits)

No Longer applicable in the revisions

- P.5 Richards \& Chauveau. Fixed

- P.5 See also Richards et al. Community cohesion in Liberia: a post-conflict rapid social assessment (2005)

This paper says basically the same things as the above paper. So we felt that it is not important to add this reference.

- P.6 "...and loot (vehicles, etc.)" What is the point of quoting here and the previous quote: please reflect on the quotes.

Fixed (and moved elsewhere in the paper and properly contextualized).

- P.6 "The latter in particular.." You use "detailed situational analyses" and later you use "snapshot" to refer to the same set of reports.

No longer relevant in the revision. Wording has been removed.

- P.6 Footnote 8. There is a reference to a footnote in the footnote and Outram 1997 must be 1999. Also was the True Whig Party also not the de jure ruling government.

No longer relevant. In an effort to shorten the paper, much of the political analysis has been removed. 
- P.7 First sentence must be rephrased: policy infrastructure? Providing a badly-needed boost? Revision does not contain this phrase.

- P.7 "... sub-Saharan African Africa" is one Africa too much. We prefer 'sub-Saharan Africa'.

- P.8 " ... largely outside the monetized economy.." $\$ 70$ per capita may sound worse than it is if all ones needs are fulfilled through trade outside the monetized economy. No - we have explained why.

- P.8 "..the price of subsidized rice..." add "local" before "rice". Revision does not contain this phrase.

- P.8 You provide a short historical analysis of agriculture in Liberia but you do not provide a historical analysis of diamond mining in Liberia. Please add. The revised paper better contextualizes the diamond mining issue. An lengthy description is not, in our view, necessary at this point.

- P.8 " ... a preconceived notion..." Perhaps this was based on wartime experiences where many combatants where involved in mining (also in close by Sierra Leone) Revision does not contain this phrase.

- P.8 " ... in each of these countries" reference needed. This, we feel, is common knowledge.

- P.8 "... little to disassociate the country's" Not sure if I read this in the quote on the following page: the fact that the potential of diamonds to fuel conflict is acknowledged is not enough (this is also recognized by the author - see comment above) This is our view. We believe that it is pretty much a consensus.

- P.9 ".. are far too small in scale to have a lasting impact" This is a bit of a sweeping statement if these projects are not discussed or if one does not define "lasting impact". Rephrased.

- P. 9 "The 90 percent increase in FDI..." FDI? Revision does not contain this phrase.

- P.9 A US $\$ 3$ billion contract does sound significant, and would bring a major increase of 1.9 million collect in 2007, or is this wrong? Not really. We believe that the readers of JDS are acquainted well enough with the dynamics of aid to realize that this is not much money.

- P.9 "... export-led growth.." It has worked in Botswana Revision does not contain this phrase.

- P.10 " because of security.." "Security" is not clear here. Revision does not contain this phrase.

- P.10 you might want to read Reno 1995 on Sierra Leone and the different diamond mining schemes

We believe that this is beyond the scope of this paper. The aim is to document the interconnectedness of the activities, not to talk about Sierra Leone's diamond mining schemes. We have already discussed at length the licenses available in Liberia.

- P.10 "... are interconnected?" in some places though Revision does not contain this phrase.

- P.12 "... in favour of improved security..." explain and add references. Revision does not contain this phrase.

- P.12 "...donors may, in fact..." and the Liberian government perhaps as well. Revision does not contain this phrase. 
- P.13 First quote is not really clear

The quote is explained.

- P.13 The back to the soil campaign has "gripped the nation" but "simply does not have the reach" contradictory.

Yes, we agree with this. We have clarified.

- P. 14 The first quote is not capturing the unrealistic expectations.

We believe it is. We have documented the conditions in which these people are working.

- P.14 "It appears... donor programme" Obscure sentence.

Revision does not contain this phrase.

- P.14 "... have had a positive impact.. " any evidence for this?

Revision does not contain this phrase.

- P.15 " it nearly 25 percent..." Closer to $15 \%$

Fixed.

- P.15 Footnote 14. There is very limited information about the sample (age, household size, size of land, etc.) Also, interviewing family heads gives a very specific picture.

Throughout, we have provided more detail of the $\mathbf{3 0}$ people interviewed in the pilot research. We want to clarify as well that it was pilot research. Moreover, we are trying our best to respect our promise to preserve anonymity here. But we have done a better job of describing, in the revision, who was interviewed.

- P.16 "...only 10 local miners..." who are these miners: landless people, youth, big miners/contractors?

All of the people in the town are quite poor. This is rather obvious from the discussion. There are no contractors.

- P.17 "... many people don't have the money to mine..." so mining is a luxury, a demand pull.

No - this is also made clear.

- P.18 "... important light on this important issue" writing style, $2 x$ important.

We thought the writing was fine but it has been revised.

- P.18 " He currently has four...(...) Charles Taylor seized power" This whole section is not really relevant.

This has been fixed.

- P.18 "... is very much a pre-war phenomenon" So what is new now, why should I read this rather than an article dating back to before 1989 ?

we are trying to establish when the diversification began. It is very important, in our view.

- P. 20 "the aforementioned..." why could it not happen if local gov officers do not derive something? 
This, we believe, is made clear.

- P.20 "Revitalization...." Did you not mention before that there was little donor interesting in mining?

\section{Revision does not contain this phrase.}

- P.20 "these bribes or ..." What would happen if the officers could not be bribed? Would it make a difference: there are way too few officers on the ground (and badly equipped) to really check on all the mining activities, is it not?

We really think that this is beyond the scope of this investigation.

- P.21 "Under the government of warlord..." "warlord-turned-President" would be better.

Fixed.

- P.21 Most Artisanal mining activities would perfectly be covered under licence class C (unless people are not allowed to use water-pumps). Guess that it is mainly the costs rather than the fact that they are not allowed to use heavy duty earth moving equipment which "proved crippling"

Yes, and the slow rate at which economic stones are found using manual implements. This is made clear. People are not allowed to use water pumps, no.

- P.22 "unlikely to address it" But in the next sentence there is "considerable preoccupation at the highest levels.." Contradictory.

Revision does not contain this phrase.

- P.23 "... are manual and inefficient..." Are the methods inefficient for ASM standards?

We do not know what this means. Most ASM in sub-Saharan Africa is inefficient.

- P. 24 "Mr Conteh employs 35 workers..." Are these all fed from his own farm and by rice produced by his family, He must be a big landowner then with loads of labour at his disposal.

We do not see how this is the case. 35 workers means 35 cups of rice.

- P.24 Indented quote not strong (particular second half)

Revision does not contain this phrase.

- P.24 "... any chance of ..." Any evidence for this statement?

Revision does not contain this phrase.

- P.25 "There are signs..." What are these signs?

Revision does not contain this phrase.

- P.25 "A successful move into..." Is a move rather than a successful move also a route out of poverty?

Revision does not contain this phrase.

- P. 25 "The latter, which could..." To what refers "latter"? 
Revision does not contain this phrase.

Referee: 2

Comments to the Author

The paper succeeds in what it sets out to achieve by exploring the relationship between artisanal diamond mining and rural lives in post-conflict Liberia. However, much of the discussion lacks substantive detail and data making parts of the discussion weak. This is especially the case with the second half of the paper which lacks substantive details about how farming and mining are structured and what the economic pros and cons might be for thoise making these decisions. Overall, there is little concrete data that would demonstrate 'proof', that the process to develop a unique coping strategy is indeed occurring, or if in fact it is unique.

Suggested revisions

The following remarks point to the areas in which data is required or recommended:

- The paper manages to convey the relationship between artisanal diamond mining and farming however, there is little substantive data or detail to illustrate how and why people move into diamond mining. We are told it is due to poverty, but this is not explained. What is poverty in this context? What does it look like? Are some people or households more vulnerable to poverty than others and how does this affect livelihood diversification strategies? What is the cost of imported rice compared to local rice for average household budgets? When is a rice crop uneconomical (for market sale)? Such data would allow the reader to develop a picture of the varying constraints and possibilities that inform the decision to take up artisanal mining and continue farming at the same time.

We believe that the revision helps to provide a clearer view of the situation in the rice sector and therefore why people are moving into diamond mining. We have to bear in mind that the literature on Liberia is rather scarce, so anyone writing on the topic is rather hamstrung when it comes to trying to contextualize dynamic issues such as rural poverty.

- The paper suggests that this is about coping strategies but it is unclear about who is supposed to be coping or indeed developing the strategy. Households and, what appear to be, individual entrepreneurs are mentioned, but these are not separated out as discrete strategising structures. Do households and entrepreneurial individuals face the same constraints and potential?

We believe we have made this much more clearer in the revision. We are discussing poor farm families in this paper. The $\mathbf{3 0}$ household heads interviewed are not branching out into diamond mining are not doing so to be entrepreneurial. They are poor. This is made much more clear in the revision.

- The paper talks about labour structures for farming and mining and how the latter have put people in an improved position to ease themselves out of poverty. However, these structures are not clearly described. What is the diamond value chain and labour structure? What is the link between this structure and poverty alleviation - is it enough to say this is beneficial without any evidence to illustrate how this is the case?

We did not want to get into a discussion on labour structures. We felt that this beyond the scope of the paper. The main issue the paper wished to discuss was the livelihood diversification pattern emerging.

- The issue of access to land is crucial to this discussion and is alluded to; however, what we are not told is: how the land 
tenure system operates (there is mention of chiefly authority but not in relation to land); how land is apportioned for mining and farming and if there is conflict between the two; and if 'rent' of diamond mining land is a feature in this area as elsewhere in Africa where informal mining takes place.

Anyone who knows the situation in Liberia knows that this is an issue that is impossible to address in its entirety: there are no land deeds, people have migrated, and disagreements over land transactions are filling the courts. This is beyond the scope of the analysis but we though it was useful to describe the land situation briefly, and have done so on page 8, referring specifically to the situation in Tubmanburg.

It is worth considering the truncation of the discussion in the first half of the paper to make space for greater detail and data in the second half. This would allow the argument to be driven home more forcefully.

It has been reduced considerably.

In addition, the paper requires considerable editing to ensure sentences are clear throughout the text, that spelling and grammatical errors are removed.

To conclude, the paper provides a useful and interesting contribution to the academic discussion around the status of artisanal mining in policy circles and within governmental poverty reduction agendas. Doing this through data collected from the field in Liberia, where there is a real dearth of material on ASM and rural livelihoods in the post-war context, is, in some respects, a signifcant contribution to knowldege about the area and topics discussed. However, a paper of this sort, which attempts to describe economic and cultural processes of change, requires substantial data to esnure the the links between ASM, farming and 'strategising for survival' etc are clear and unequivocal. 